\title{
Structural characterization of a compacted alfisol under different tillage systems
}

\author{
N. Brunel-Saldias ${ }^{1 *}$ I. Martínez ${ }^{2}$, O. Seguel ${ }^{3}$, C. Ovalle ${ }^{4}$, E. Acevedo
}

${ }^{1}$ Plant Breeding and Phenomic Center, Facultad de Ciencias Agrarias, PIEI Adaptación de la Agricultura al Cambio Climático (A2C2), Universidad de Talca, Chile.

${ }^{2}$ Instituto de Investigaciones Agropecuarias INIA, Chillán, Chile.

${ }^{3}$ Department of Engineering and Soils, Universidad de Chile, Facultad de Ciencias Agronómicas, Santa Rosa 11315 La Pintana, Santiago, Chile.

${ }^{4}$ Instituto de Investigaciones Agropecuarias (INIA), Calle Chorrillos 86, La Cruz, Chile.

${ }_{5}^{5}$ Soil- Plant - Water-Relations Laboratory, Universidad de Chile, Facultad de Ciencias Agronomicas, Santa

Rosa11315 La Pintana, Santiago, Chile.*Corresponding author: nidiabrunel@gmail.com

\begin{abstract}
Conservation tillage is a management system used to mitigate and rehabilitate the dryland areas of southerncentral Chile in severely compacted soils. The objective of this study was to evaluate the soil physical properties in the root zone under an oat-wheat crop rotation after three years of the establishment of three tillage systems: conventional tillage (CT), zero tillage (ZT) and zero tillage with subsoiling (ZTS). Soil bulk density, porosity, water retention curve, stability of macro- and microaggregates, airflow at field capacity, rest coefficient, and number of roots were evaluated. The results showed that the soil had low water holding capacity in the profile due to the low water retention at the permanent wilting point (matric water potential lower than $-1.500 \mathrm{kPa}$ ), associated with a high bulk density and clay content. The conservation tillage systems (ZT and ZTS), were similar in the parameters of fast drainage pores (FDP), aggregate stability index, airflow, and rest coefficient compared with CT. However, the volume of pores with diameters between $10-50 \mu \mathrm{m}$ was higher in ZTS in a $24 \%$ and $13 \%$, compared with ZT and CT, respectively. In addition, the root development increased significantly in ZTS. In conclusion, the physical condition of the compacted soil was improved by the zero tillage system with subsoiling, which promoted a better root system in the first horizons in highly compacted soils.
\end{abstract}

Keywords: Subsoiling, rooting, porosity 


\section{Introduction}

The interior dryland of the central Chilean coastal range is a geographic area associated with a Mediterranean climate where granitic and metamorphic soils, especially Alfisols, are highly susceptible to soil erosion. This agroclimatic zone has historically been cropped to cereals and intensive conventional tillage practices, which have led to a progressive reduction of soil productivity. Conservation tillage systems have the potential to mitigate soil erosion in these degraded soils (Martínez et al., 2012). It has been observed in the first $15 \mathrm{~cm}$ of soil that improving water retention capacity and soil structure, results in higher root development of wheat under zero tillage management (Lampurlanés and CanteroMartínez, 2003; Martínez et al., 2008). It has also been observed that no-tillage compacts clay textured soils negatively affects deep root growth and water absorption from deeper horizons; this is an unfavorable situation for crops in dryland zones (Alvarez and Steinbach, 2009). Subsoiling technique -as a complement to zero tillage-, helps to reduce soil compaction in deep, facilitates root growth and let to greater utilization of water stored in the $50-110 \mathrm{~cm}$ soil (Martínez et al., 2011). A complementary effect is that additional water is stored in the root growth zone of the soil and improves plant water availability, which is essential for plants to resist drought periods (Hong-Ling et al., 2008). We test the hypothesis that conservation tillage systems improve the physical conditions of the soil profile of highly degraded soil as compared to conventional tillage. Conventional tillage has been used for many years and has increased the problem in the study area. The objective of this study was to evaluate the soil physical properties in the root zone of a wheat crop after 3 years of conventional tillage and compare it with two conservation tillage systems.

\section{Materials and Methods}

\subsection{Site description}

The experiment was carried out from 2007 through 2010 at the INIA Cauquenes Experimental Center (35 ${ }^{\circ}$ $\left.97^{\prime} \mathrm{S}, 72^{\circ} 24^{\prime} \mathrm{W}\right)$. The site is characterized by a subhumid Mediterranean climate with an average annual rainfall of $690 \mathrm{~mm}$ and annual mean temperature of $14.7^{\circ} \mathrm{C}$. The temperature fluctuates between a maximum mean of $27^{\circ} \mathrm{C}$ in January and a minimum mean of $4.7^{\circ} \mathrm{C}$ in July. The soil is an Alfisol belonging to the Cauquenes Association and classified as Ultic Palexeralf, developed in situ from granitic rock and dominated by fine textural classes, clay loam on surface over dense clay in depth. Prior site management consisted of natural grassland for direct sheep grazing. The site is located in the upper part of a hillside with eastern exposure and it has a $12.5 \%$ slope. It had homogeneous initial water corroborated by soil morphological descriptions for the three plots established in the study. Table 1 shows values of physical properties of the 0-100 cm depth at the start of the trial (2007).

\subsection{Description of the field experiment}

Three tillage systems were studied: conventional tillage (CT) and two conservation tillage systems, zero tillage (ZT) and zero tillage with subsoiling (ZTS). Conventional tillage was the control and corresponded to the CT system used by farmers in the zone. This technique used a moldboard plow passed at $20 \mathrm{~cm}$ depth with animal traction. Winter oat/wheat were sown manually. Zero tillage in ZT and ZTS systems was done with a no-till seeder, the planter (Vence Tudo, Chile) was drawn by oxes and had 7 rows 17 $\mathrm{cm}$ apart, and subsoiling in ZTS was carried out in the first year of the study (2007) only. A subsoiler chisel plow was passed in April at $40 \mathrm{~cm}$ depth and $40 \mathrm{~cm}$ 
spacing in the direction perpendicular to the slope. Stubble cover equivalent to $2.5 \mathrm{Mg} \mathrm{ha}^{-1}$ shredded harvest cereal residue (oats or wheat in according to crop rotation) was maintained in the two soil conservation systems. The plot size was $1000 \mathrm{~m}^{2}$.

The sowing date was close to 15 May each year. Plot management consisted in a crop rotation of oats ( $A v$ ena sativa cv. Supernova-INIA in 2007 and 2009) and wheat (Triticum aestivum cv. Pandora-INIA in 2008). Sowing rates were $140 \mathrm{~kg}$ seed ha $\mathrm{h}^{-1}$ for oats and 200 $\mathrm{kg}$ seed ha $\mathrm{h}^{-1}$ for wheat; fertilization rates were 110,70 , and 80 units of $\mathrm{N}, \mathrm{P}_{2} \mathrm{O}_{5}$, and $\mathrm{K}_{2} \mathrm{O}$ for oats and 140, 90, and 80 units of $\mathrm{N}, \mathrm{P}_{2} \mathrm{O}_{5}$, and $\mathrm{K}_{2} \mathrm{O}$ for wheat.

\subsection{Soil evaluations}

Six randomly selected pits per treatment were sampled in Spring 2010, when the wheat crop was at the flowering stage (after 4 years of conventional and zero tillage). Soil samples were collected layerby-layer following natural soil horizons $(100 \mathrm{~cm} \mathrm{x}$ $40 \mathrm{~cm}$ cross-sectional area) down to $100 \mathrm{~cm}$ depth. The layers were 0-10, 10-30, 30-45, and 45-60 cm. At each sampling depth, undisturbed and disturbed soil samples were taken for physical analysis (144 samples, 2 undisturbed/disturbed, 4 depths $\mathrm{x} 6$ pits $\mathrm{x}$ 3 treatments).

Table 1. Baseline soil profile characteristics

\begin{tabular}{ccccccccc}
\hline Horizons & $\begin{array}{c}\text { Depth } \\
\mathrm{cm}\end{array}$ & $\begin{array}{c}\text { Sand } \\
------\end{array}$ & $\begin{array}{c}\text { Silt } \\
\%\end{array}$ & $\begin{array}{c}\text { Clay } \\
------\end{array}$ & $\begin{array}{c}\text { Textural } \\
\text { class } \\
\text { (USDA) }\end{array}$ & $\begin{array}{c}\text { Bulk } \\
\text { density } \\
\mathrm{Mg} \mathrm{m}^{-3}\end{array}$ & $\begin{array}{c}\text { Total } \\
\text { porosity* } \\
\%\end{array}$ & $\begin{array}{c}\text { Porosity } \\
\text { number (e)* } \\
\left(\mathrm{cm} \mathrm{cm}^{-3}\right)\end{array}$ \\
\hline $\mathrm{Ap}$ & $0-15$ & 72.6 & 12.6 & 14.8 & loam & 1.79 & 33 & 0.90 \\
$\mathrm{Bt}_{1}$ & $15-30$ & 42.4 & 13.0 & 44.5 & Clay & 1.69 & 36 & 0.71 \\
$\mathrm{Bt}_{2}$ & $30-60$ & 34.2 & 17.6 & 48.2 & Clay & 1.75 & 34 & 0.66 \\
$\mathrm{Bt}_{3}$ & $60-100$ & 32.2 & 19.6 & 48.2 & Clay & 1.77 & 33 & 0.63 \\
\hline
\end{tabular}

Source: DESIRE Project. * Data calculated in this study.

\subsection{Bulk density $(\mathrm{Db})$}

Bulk density was determined by the core method (Dane and Topp, 2002) in which the dry soil mass at $105{ }^{\circ} \mathrm{C}$ is related to the soil volume of the sample. Particle density (Dr) was determined by the picnometer method (Dane and Topp, 2002); the total porosity $(\mathrm{N})$, which is the ratio of the pore volume to the soil volume, as well as the porosity number (e), or ratio of the pore volume to the solid volume were calculated using the following relations:

$$
\mathrm{N}=[1-(\mathrm{Db} / \mathrm{Dr})] * 100 ; e=[(\mathrm{Dr} / \mathrm{Db})-1]
$$

where $\mathrm{N}$ is the total porosity (\%), e is the pore number $\left(\mathrm{cm}^{3} \mathrm{~cm}^{-3}\right), \mathrm{Db}$ is the bulk density of the core $(\mathrm{Mg}$ $\left.\mathrm{m}^{-3}\right)$, and Dr is the particle density $\left(\mathrm{Mg} \mathrm{m}^{-3}\right)$. The bulk density was also measured using the clod method (Dbcl) according to Dane and Topp (2002). The interaggregate porosity (Piag), which relates to the volume of pores present between the aggregates compared with the soil volume was calculated using a relationship between $\mathrm{Db}$ calculated by the core method and the clod as indicated in Equation 2 (Seguel and Horn, 2006):

$\mathrm{P}_{\text {iag }}=1-(\mathrm{Db} / \mathrm{Dbcl})$ 
where Piag is the inter-aggregate porosity $\left(\mathrm{cm}^{3} \mathrm{~cm}^{-3}\right)$, $\mathrm{Db}$ is the bulk density measured by the core method and Dbcl is the bulk density measured by the clod method.

\subsection{Soil water retention curve}

The soil water retention curve was obtained in undisturbed soil cores (height: $5.0 \mathrm{~cm}$; diameter: $5.9 \mathrm{~cm}$ ). The samples were saturated from the bottom and balanced at pressures of $0.2,6,33,100$, and $1500 \mathrm{kPa}$; the first two pressures were obtained in a sand box and the last three in a pressure plate (Dane and Topp, 2002). The pore size distribution was calculated from the soil water characteristic curve. The soil pores drained sequentially from the largest to the smallest size as the water pressure increases according to their effective radius (Hartge and Horn, 2009). Equation 3 expresses the relation of the pore size to the water extraction pressure:

$$
\mathrm{r}_{\mathrm{p}}=\left[\left(2^{*} \gamma^{*} \cos \alpha\right) /\left(\mathrm{h}^{*} \rho^{*} \mathrm{~g}\right)\right]
$$

where $r p$ is the equivalent pore radius $(\mathrm{mm}), \gamma$ is the water surface tension $\left(\mathrm{N} \mathrm{m}^{-1}\right), \alpha$ is soil to water contact angle (degrees), $\mathrm{h}$ is the capillary rise $(\mathrm{cm})$ in the pore of radius rp from the sand-box or the pressure chamber, $\rho$ is the water density $\left(\mathrm{Mg} \mathrm{m}^{-3}\right)$, and $g$ is the acceleration due to gravity $\left(\mathrm{m} \mathrm{s}^{-2}\right)$. Bearing in mind that for the soil wetting angle $(\alpha)$, perfect wetting is considered when $a=0,(\cos \alpha=1)$, water drained at a determined pressure or height (h) comes from a pore with an equivalent radius equal to or greater than the behavior of the capillary tube radius $\mathrm{rp}$. The equilibrium pressures determined in the soil water retention curve (matric potential) allow classifying the soil pores in fast drainage pores (FDP) $(>50 \mu \mathrm{m})$, as the difference in water content between matric equilibriums of -0.2 and $-6 \mathrm{kPa}$, slow drainage pores (SDP) $(10-50 \mu \mathrm{m})$, as the difference in water content between matric equilibriums of -6 and $-33 \mathrm{kPa}$, and useful water for plants (UW) $(0.2-10 \mu \mathrm{m})$, as the difference in soil water content between soil matric potentials of -33 and $-1500 \mathrm{kPa}$ (Hartge and Horn, 2009).

\subsection{Macro-aggregate stability}

Macro-aggregate stability was determined by the dry and wet sieving method (Hartge and Horn, 2009). The disturbed samples were air-dried, $200 \mathrm{~g}$ subsample of aggregates (dry soil exposed to air and up to $3 \mathrm{~cm}$ diameter) were randomly taken from each sample and placed on a set of sieves with diameters of $19,9.5,6.35,4.75,3.33$, and $2 \mathrm{~mm}$. The subsample was sieved for $2 \mathrm{~min}$ at a frequency of $60 \mathrm{~Hz}$ and the sample water content was determined. Once the dry sieving was finished, the aggregate mass left in each sieve was determined and the partial fraction of each size (ratio between sieve soil mass and total soil mass) was calculated and corrected for its water content to determine the initial distribution of aggregate sizes. A second sieving was then done under water where the set of sieves was shaken with $5 \mathrm{~cm}$ upward and downward movements for $5 \mathrm{~min}$ at $60 \mathrm{rpm}$. The soil remaining in each sieve was dried at $105^{\circ} \mathrm{C}$ for $16 \mathrm{~h}$ or more to determine the aggregate fraction for each size. The variation of weighted mean diameter $(\triangle \mathrm{WMD})$ was determined with the results of the dry and wet sieving (Hartge and Horn, 2009) by the equation:

$$
\Delta W M D(m m)=\frac{\sum\left(n_{i 1} \times d_{i}\right)-\left(n_{i 2} \times d_{i}\right)}{n_{i 1}}
$$

where $d$ is the aggregate mean diameter in range $i$ that corresponds to each range of sieves being used (in the present study: $24.50,14.25,7.93,5.55,4.04,2.67$, and $1.00 \mathrm{~mm}$ ), ni1 is the dry mass of the fraction in range $i$ for dry sieving, and $n i_{2}$ is dry mass in range $\mathrm{i}$ of wet sieving. Therefore, with the results of both sievings (dry and wet), a stability analysis is performed for 
each natural aggregate size range from a known distribution of aggregates obtained in dry sieving. The lowest $\triangle \mathrm{WMD}$ value indicates the highest soil stability (Hartge and Horn, 2009).

\subsection{Micro-aggregate stability}

Micro-aggregate stability was determined by the dispersion ratio (DR) method described by Seguel et al. (2003). Two soil samples of $50 \mathrm{~g}$ with aggregates between 1 and $2 \mathrm{~mm}$ diameter were obtained by sieving air-dried soil; one of the subsamples was subjected to a slight dispersion in $150 \mathrm{~cm}^{3}$ distilled water, while the other sample was subjected to a drastic dispersion with the same amount of distilled water and $20 \mathrm{~cm}^{3}$ of sodium pyrophosphate. Both samples were left to rest during the night. The drastically dispersed sample was then mechanically shaken for $10 \mathrm{~min}$ in a 75 cycle Hamilton Beach blender. Finally, the samples were poured into $1 \mathrm{~L}$ measuring cylinders filled up to 1000 $\mathrm{cm}^{3}$ with distilled water. The density of the suspension was measured with a hydrometer along with the temperature $40 \mathrm{~s}$ after the start of the decanting process. The clay and silt content of both samples was calculated by the Bouyoucos hydrometer method based on Stoke's law (Dane and Topp, 2002) using the equation:

$$
\mathrm{DR}=[(\mathrm{S}+\mathrm{C}) \mathrm{sd} /(\mathrm{S}+\mathrm{C}) \mathrm{dd}] * 100
$$

where DR is the dispersion ratio, $(\mathrm{S}+\mathrm{C})$ sd is the percentage of silt and clay found in the sample with slight dispersion (sd) and ( $\mathrm{S}+\mathrm{C}) \mathrm{dd}$ is the percentage of silt and clay found in the sample with drastic dispersion (dd). The lowest DR value indicates the highest soil stability

\subsection{Airflow at field capacity}

Airflow was measured similar to that described by Peth (2004), using undisturbed soil samples equilibrated on water retention at $-33 \mathrm{kPa}$. The base of the cylinder was connected to a vacuum chamber resting on a container with water to maintain the vacuum. Suction was applied to cause airflow between the atmosphere and the chamber at time t. The vacuum was $0.1 \mathrm{kPa}$, which was measured by a $1 \mathrm{~cm}$ difference in height of a water manometer. Air volume (V) that flowed into the soil sample was determined by the formula:

$\mathrm{V}=\mathrm{h} * \pi *(R c)^{2}$

where $\mathrm{V}$ is air volume $\left(\mathrm{cm}^{3}\right)$ that flew through the soil sample and entered the vacuum chamber at time $t, h$ is the height at which the vacuum chamber is lifted above the water level $(\mathrm{cm})$, and $\mathrm{Rc}$ is the radius of the vacuum chamber $(\mathrm{cm})$ on which the soil sample is attached. Airflow was then determined by equation 7 (Peth, 2004):

$$
\mathrm{F}_{\text {air }}=\rho_{1} * \mathrm{~g} *(\mathrm{~V} * \mathrm{~L} / \mathrm{t} * \Delta \mathrm{p} * \mathrm{~A})
$$

where Fair is the airflow $\left(\mathrm{m} \mathrm{s}^{-1}\right), \rho l$ is air density during measurement $\left(1.228 \mathrm{~kg} \mathrm{~m}^{-3}\right.$, considering an atmospheric pressure of 1033 mbar and temperature of 20 $\left.{ }^{\circ} \mathrm{C}\right), \mathrm{g}$ is the acceleration due to gravity $\left(9.81 \mathrm{~m} \mathrm{~s}^{-2}\right)$, $\mathrm{V}$ is the volume of air that flows through the sample $\left(\mathrm{m}^{3}\right), \mathrm{L}$ is the length of the soil sample $(\mathrm{m}), \mathrm{t}$ is measured time (s) for the volume $\mathrm{V}, \Delta \mathrm{p}$ is the difference in pressure $(\mathrm{hPa})$ recorded on the water manometer, and A is the cross-sectional area of the soil sample $\left(\mathrm{m}^{2}\right)$.

\subsection{Rest coefficient}

Soil mechanical impedance was measured vertically and horizontally with a cone penetrometer (EXTECH mod. 475044). Four horizontal and four vertical measurements were taken in each sampling unit (soil pit), which covered a $40 \mathrm{~cm}$ wide and 10 $\mathrm{cm}$ deep area in the Ap horizon; the rest coefficient (ko) was calculated as the ratio between horizontal and vertical impedance, where ko $>1$ reveals soil compaction (Hartge and Bachmann, 2004). 
No further measurements were taken since low soil moisture conditions at greater depths caused resistance values to exceed the equipment's measurement capability $(0-200 \mathrm{Nt})$.

\subsection{Roots}

To visualize the root growth, four grids $\left(10 \times 10 \mathrm{~cm}^{2}\right)$ were traced on a $40 \mathrm{~cm}$ wide and down to $80 \mathrm{~cm}$ depth (White and Kirkegaard, 2010). The number of roots was counted for each layer with six replicates and was described in accordance with size class: fine to very fine $(<2 \mathrm{~mm})$, medium ( 2 to $5 \mathrm{~mm}$ ), and coarse (5 to $10 \mathrm{~mm}$ ) according to Schoeneberger et al. (2002).

\subsection{Statistical analysis}

The data were collected with six replicates from each treatment. We used the Anderson-Darling test to verify the assumption of normality, and Bartlett's test for homogeneity of variances. After the verifications of assumptions of the error terms, datas were subjected to ANOVA with a completely randomized design with a factorial structure, where the effect of the tillage systems in each physical parameter was analyzed with two factors (tillage systems and depth). When corresponded, means were compared by Tukey's test $(\mathrm{p} \leq 0.05)$ with the SAS statistical program (SAS Institute, 1999).

\section{Results}

\subsection{Soil density and porosity}

The results of bulk density $(\mathrm{Db})$ and total porosity (N) after three-year crop rotation system under conventional (CT) and zero tillages sytems (ZT and ZTS) are shown in Table 2 . In the topsoil $(0-10 \mathrm{~cm}$ depth), $\mathrm{Db}$ was significantly lower in the three tillage systems $\left(1.39 \mathrm{Mg} \mathrm{m}^{-3}\right)$; at this depth it was lower in $\mathrm{CT}$ although the differences were not significant. Total porosity $(\mathrm{N})$ were higher in the topsoil $\left(48 \% \mathrm{~cm} \mathrm{~cm}^{-3}\right)$, with no difference between treatments and a trend of higher values in CT.

Table 3 shows that inter-aggregate porosity was higher in the upper $(0-10 \mathrm{~cm})$ than in the rest of the soil profile. There was no significant interaction between factors and tillage systems. ZT had the lowest values below $30 \mathrm{~cm}$ of depth; while the higher values were observed in CT and ZTS, which is not necessarily related to a higher structural porosity, but they could correspond to cracks caused by drying, so that its functionality should be analyzed together with other soil properties.

\subsection{Pore size distribution}

There were no significant differences in the slopes of the curves for each horizon among tillage systems (data not shown). There was a higher total porosity at the surface $(0-10 \mathrm{~cm})$ with a high slope between saturation (pressure $=0$ ) and field capacity $(\mathrm{FC},-33$ $\mathrm{kPa}$ ), which indicates an abundance of coarse pores. The soil water retention at low pressures is related to the structural conditions, while at high pressures to the soil texture (Hartge and Horn, 2009). The soil water retention curve indicates that the volume of small pores $(<0.2$ $\mu \mathrm{m})$ increased with soil depth and clay content $(>44.5 \%$ of clay at $15 \mathrm{~cm}$ depth; Table 1). It was found that the maximum water storage capacity for the first horizon $(0-20 \mathrm{~cm})$ was around $40 \mathrm{~mm}$ of water.

Pore size distribution was derived from the water retention curve (Equation 3) and defined in Table 4, as fast drainage $(>50 \mu \mathrm{m})$, slow drainage $(10-50 \mu \mathrm{m})$ and usefull water pores $(0.2-1.0 \mu \mathrm{m})$. Fast drainage pores were greater at $0-10 \mathrm{~cm}$ of depth, but similar between treatments; while at greater depths (below $30 \mathrm{~cm}$ depth), significantly decreased the coarse porosity ( $\mathrm{p} \leq 0.05)$, which possibly could affect the soil aeration and root growth potential. In contrast, slow drainage pores were higher under ZTS than CT and ZT; this difference can be important when 
plant water availability is determined by water contained in slow drainage pores. Although it is difficult to show a value for pore space which suppress root growth, some authors have observed that macro-porosity should be greater than $10 \%$ for adequate elongation and maximum root growth (Richards, 1983). The fast drainage pores (Table 4) had values greater that or equal to $10 \%$ up to 45 $\mathrm{cm}$ depth, except for ZT in the 30-45 cm depth. Finally, the usefull water pores were higher in CT than ZTS.

Table 2. Bulk density, total porosity $(\mathrm{N})$, and pore number (e) in accordance with tillage systems.

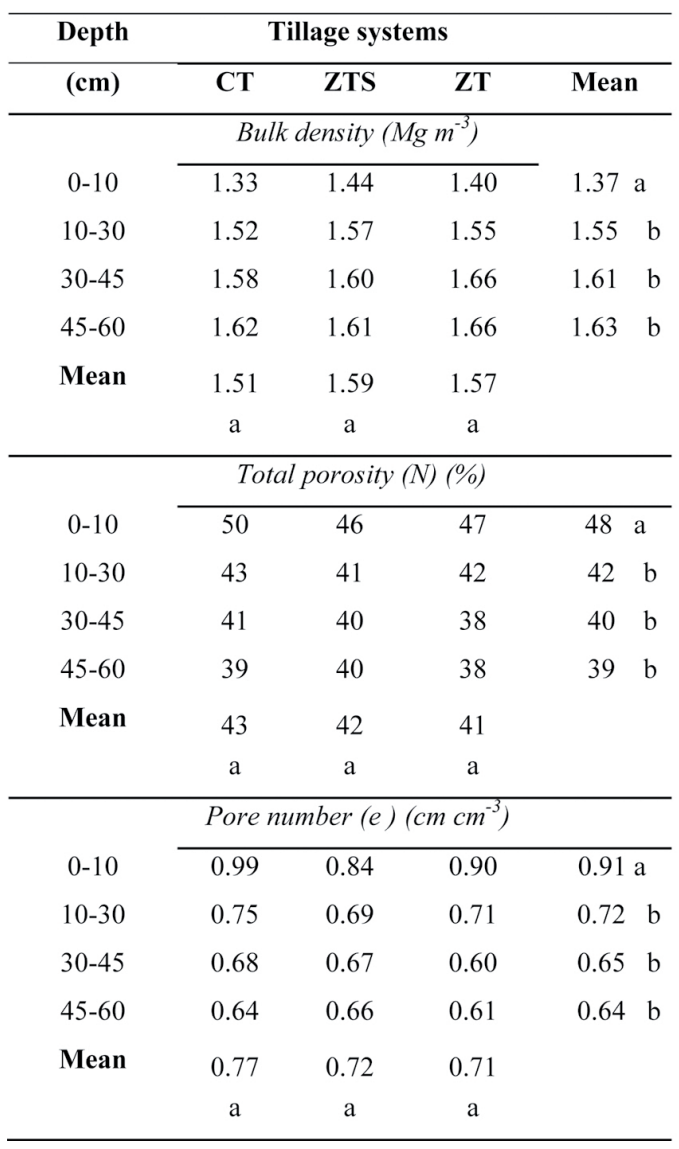

CT: Conventional tillage; ZTS: Zero tillage with subsoiling,ZT:Zero tillage. Means for tillage systems (rows) and depth (columns) with the same letter are not significantly different $(\mathrm{p} \leq 0.05)$.
Table 3. Inter-aggregate porosity (\%) in accordance with tillage systems.

\begin{tabular}{ccccccc}
\hline $\begin{array}{c}\text { Depth } \\
(\mathbf{c m})\end{array}$ & \multicolumn{3}{c}{ Tillage systems } & & \multicolumn{2}{c}{} \\
\cline { 2 - 4 } & CT & ZTS & ZT & Mean & \\
\hline $0-10$ & 22 & 21 & 23 & 22 & $\mathrm{a}$ & \\
$10-30$ & 14 & 12 & 15 & 14 & $\mathrm{~b}$ \\
$30-45$ & 9 & 10 & 6 & 8 & $\mathrm{~b}$ \\
$45-60$ & 11 & 11 & 6 & 9 & $\mathrm{~b}$ \\
Mean & 14 & 14 & 13 & & \\
& $\mathrm{a}$ & $\mathrm{a}$ & $\mathrm{a}$ & &
\end{tabular}

CT: Conventional tillage; ZTS: Zero tillage with subsoiling, ZT: Zero tillage. Means for tillage systems (rows) and depth (columns) with the same letter are not significantly different $(p \leq 0.05)$.

Table 4. Pore size distribution (\%) as related to tillage systems.

\begin{tabular}{|c|c|c|c|c|c|c|}
\hline \multirow{2}{*}{$\begin{array}{l}\text { Depth } \\
(\mathrm{cm})\end{array}$} & \multicolumn{3}{|c|}{ Tillage systems } & \multirow[b]{2}{*}{ Mean } & \\
\hline & CT & ZTS & ZT & & & \\
\hline & \multicolumn{3}{|c|}{ Fast drainage pores $(>50 \mu \mathrm{m})$} & & & \\
\hline $0-10$ & 23.6 & 19.6 & 22.8 & 22.0 & a & \\
\hline $10-30$ & 14.0 & 16.7 & 15.1 & 15.0 & b & \\
\hline $30-45$ & 11.6 & 10.3 & 8.7 & 10.0 & & $\mathrm{c}$ \\
\hline $45-60$ & 8.7 & 9.3 & 9.4 & 9.0 & & $\mathrm{c}$ \\
\hline \multirow[t]{2}{*}{ Mean } & 14.5 & 14.0 & 14.0 & & & \\
\hline & $\mathrm{a}$ & $\mathrm{a}$ & $\mathrm{a}$ & & & \\
\hline & \multicolumn{3}{|c|}{ Slow drainage pores $(10-50 \mu \mathrm{m})$} & & & \\
\hline $0-10$ & 8.3 & 8.3 & 6.3 & 7.6 & a & \\
\hline $10-30$ & 6.6 & 9.0 & 6.6 & 7.4 & a & \\
\hline $30-45$ & 4.8 & 4.8 & 4.3 & 4.6 & b & \\
\hline $45-60$ & 3.9 & 5.0 & 3.6 & 4.2 & b & \\
\hline \multirow[t]{2}{*}{ Mean } & 5.9 & 6.8 & 5.2 & & & \\
\hline & $\mathrm{b}$ & a & $b$ & & & \\
\hline & \multicolumn{3}{|c|}{ Usefull water pores $(0.2-10 \mu \mathrm{m})$} & & & \\
\hline $0-10$ & 6.6 & 5.5 & 6.3 & 6.1 & a & \\
\hline $10-30$ & 6.2 & 4.5 & 5.0 & 5.2 & $a b$ & \\
\hline $30-45$ & 4.7 & 4.1 & 3.9 & 4.3 & & $\mathrm{c}$ \\
\hline $45-60$ & 4.2 & 3.0 & 3.2 & 3.5 & & $\mathrm{c}$ \\
\hline \multirow[t]{2}{*}{ Mean } & 5.4 & 4.3 & 4.6 & & & \\
\hline & $\mathrm{a}$ & b & $\mathrm{ab}$ & & & \\
\hline
\end{tabular}

CT: Conventional tillage; ZTS: Zero tillage with subsoiling, ZT: Zero tillage. Means for tillage systems (rows) and depth (columns) with the same letter are not significantly different $(\mathrm{p} \leq 0.05)$. 
Table 5. Aggregate stability ( $<3 \mathrm{~cm}$ diameter) as related to tillage systems.

\begin{tabular}{|c|c|c|c|c|c|}
\hline \multirow{2}{*}{$\begin{array}{c}\text { Depth } \\
\text { cm }\end{array}$} & \multicolumn{3}{|c|}{ Tillage systems } & \multirow[b]{2}{*}{ Mean } & \\
\hline & CT & ZTS & ZT & & \\
\hline & \multicolumn{3}{|c|}{ Macro-aggregate stability } & & \\
\hline & \multicolumn{3}{|c|}{$\Delta \mathrm{WMD}(\mathrm{mm})$} & & \\
\hline $0-10$ & 3.72 & 3.22 & 1.78 & 2.91 & c \\
\hline $10-30$ & 6.54 & 4.92 & 5.68 & 5.71 & $\mathrm{~b}$ \\
\hline $30-45$ & 6.41 & 7.81 & 7.19 & 7.14 & $\mathrm{a}$ \\
\hline $45-60$ & 8.00 & 8.47 & 8.32 & 8.26 & $\mathrm{a}$ \\
\hline \multirow[t]{4}{*}{ Mean } & 6.17 & 6.11 & 5.74 & & \\
\hline & a & $\mathrm{a}$ & a & & \\
\hline & \multicolumn{3}{|c|}{ Micro-aggregate stability } & & \\
\hline & \multicolumn{3}{|c|}{ DR $(\%)$} & & \\
\hline $0-10$ & 41 & 30 & 36 & 36 & $\mathrm{a}$ \\
\hline $10-30$ & 12 & 30 & 21 & 21 & $\mathrm{~b}$ \\
\hline $30-45$ & 11 & 9 & 15 & 12 & c \\
\hline $45-60$ & 16 & 13 & 16 & 15 & b c \\
\hline \multirow[t]{2}{*}{ Mean } & 20 & 21 & 22 & & \\
\hline & $\mathrm{a}$ & $\mathrm{a}$ & $\mathrm{a}$ & & \\
\hline
\end{tabular}

CT: Conventional tillage; ZTS: Zero tillage with subsoiling, ZT: Zero tillage, $\triangle \mathrm{WMD}$ : variation of weighted mean diameter, DR: dispersion ratio. Means for tillage systems (rows) and depth (columns) with the same letter are not significantly different $(\mathrm{p} \leq 0.05)$.

\subsection{Aggregate stability}

Aggregate stability was significantly different for soil depth (macro and microaggregate), as shown in Table 5. Macro-aggregate stability (1-30 mm), was evaluated by the variation of weighted mean diameter $(\triangle \mathrm{WMD})$, and micro-aggregate stability (1 to 2 $\mathrm{mm}$ ) was evaluated by the dispersion ratio (DR). The lowest value for each index indicates a higher aggregate stability (equations 4 and 5). The DR index, associated with micro-aggregates, decreased (higher stability) as soil depth increased; however, macroaggregate stability increased (lower stability) as soil depth increased (Table 5).
According to Seguel et al. (2003), DR values lower than $30 \%$ correspond to highly stable soils, where the clay content plays an important role in the formation of micro-aggregates. Both index are related to soil structure; while the stability of micro-aggregates was associated to a high clay content, which drastically increased from $20 \mathrm{~cm}$ depth downwards (Table 1); macro-aggregate was realted to soil organic matter, which was higher at the surface of the profile.

\subsection{Pore system functionality}

Figure 1 illustrates airflow at increasing soil depths measured from samples equilibrated at field capacity $(-33 \mathrm{kPa})$. Airflow increased significantly $(\mathrm{p} \leq 0.05)$ as soil depth increased, contrary to the coarse pore distribution in the profile, with means of $6.8 \mathrm{~cm} \mathrm{~h}^{-1}$ in the first horizon $(0-10 \mathrm{~cm})$ to $21.4 \mathrm{~cm} \mathrm{~h}^{-1}$ in depth $(45-60 \mathrm{~cm})$. The means between tillage systems or the soil depth by airflow interaction were significant. The trend lines of Figure 1 shows an uniform increase in airflow in the conservation tillage systems (ZT and ZTS) as soil depth increased, compared to the conventional tillage. The latter shows uneven flow with abrupt changes between horizons in $\mathrm{CT}$, which could reflect structural discontinuity within the soil profile.

\subsection{Rest coefficient}

There were no significant differences for this variable among tillage systems (data not shown). CT had a value of 1.33 , which exceeded the ko $>1$ threshold, that indicates soil compaction (Hartge and Bachmann, 2004). At the sampling date (end of October), the first soil horizon showed a water content close to the permanent wilting point, with mechanical impedance values which exceeded the equipment measuring capability (0-200 Nt) and revealed a high degree of resistance due to soil drying. 


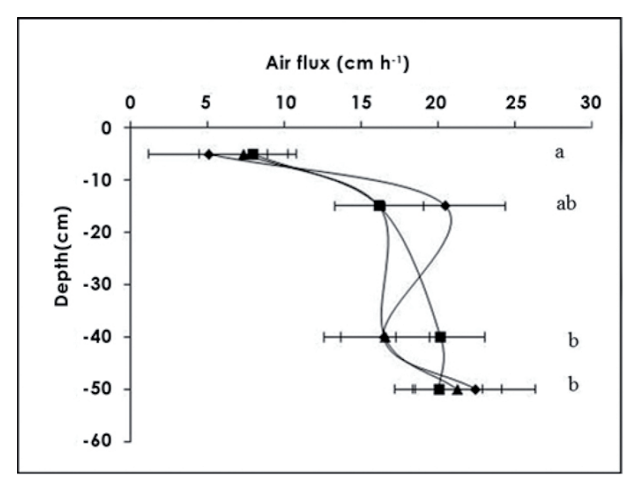

Figure 1. Airflow in soil profile in accordance with tillage systems. Horizontal bars represent standard error of the mean. Same letters indicate non significant differences ( $\mathrm{p} \leq 0.05$ ). Conventional tillage: rhombus, Zero tillage: triangles, Zero tillage with subsoiling: squares.

\subsection{Roots}

An analysis of the roots with soil depth showed the rooting pattern of the crop in the tillage systems. The fine and very fine roots ( 0 to $2 \mathrm{~mm}$ diameter) had significant differences between tillage systems. The soil depth $\mathrm{x}$ root interaction was also significant (Table 6). The roots were concentrated in the surface horizon $(0-20 \mathrm{~cm})$. The ZTS had 39 roots per $100 \mathrm{~cm}^{2}$, value significantly higher $(\mathrm{p} \leq 0.05)$ to the other tillage systems, which had means of 30 and 22 roots $/ 100 \mathrm{~cm}^{2}$ in ZT and CT, respectively. CT had significantly lower ( 36 roots $/ 100 \mathrm{~cm}^{2}, \mathrm{p} \leq 0.05$ ) roots than ZTS $\left(75\right.$ roots $\left./ 100 \mathrm{~cm}^{2}\right)$ in the first $0-20 \mathrm{~cm}$ depth, while in the total profile $(60 \mathrm{~cm}) \mathrm{CT}$ and ZT were not significantly different.
Table 6. Mean of number of roots per $100 \mathrm{~cm} 2$ for tillage systems

\begin{tabular}{ccccccc}
\hline \multirow{2}{*}{$\begin{array}{c}\text { Depth } \\
\text { cm }\end{array}$} & \multicolumn{6}{c}{ Tillage systems } \\
\cline { 2 - 7 } & $\mathbf{C t}$ & \multicolumn{2}{c}{ ZTS } & ZT \\
\hline 10 & 22.08 & $c$ & 38 & $a$ & 30.13 & $b$ \\
20 & 14.58 & $b$ & 33.67 & $a$ & 17.63 & $b$ \\
30 & 10.08 & $b$ & 17.08 & $a$ & 11.13 & $b$ \\
40 & 6.42 & $a b$ & 9.08 & $a$ & 3.63 & $b$ \\
50 & 3.17 & $a b$ & 4.58 & $a$ & 0.75 & $b$ \\
60 & 2.75 & $a b$ & 3.67 & $a$ & 0.38 & $b$ \\
70 & 0 & $a$ & 0.42 & $a$ & 0 & $a$ \\
80 & 0 & $a$ & 0.42 & $a$ & 0 & $a$ \\
\hline
\end{tabular}

CT: Conventional tillage; ZTS: Zero tillage with subsoiling, ZT: Zero tillage. Means with the same letter are not significantly different $(\mathrm{p} \leq 0.05)$.

\section{Discussion}

The bulk density of the soil ( $\mathrm{Db}$ ) was not affected by the tillage systems in spite of an input of organic mulch in the soil conservation systems of $2.5 \mathrm{Mg}$ $\mathrm{ha}^{-1}$ of crop residues. This was probably due to the low amount of organic mulch left on top of the soil, as Mulumba and Lal (2008), did not find changes in $\mathrm{Db}$ with organic mulch rates up to $16 \mathrm{Mg} \mathrm{ha}^{-1}$, or because the evaluation period was short, considering that the residue decomposition is slower when they are not incorporated in depth (Radicetti et al., 2016).Nevertheless, the presence of organic mulch most probably prevented the increase of $\mathrm{Db}$ in this clay soil (Glab and Kulig, 2008). 
The water retention curves reflected a condition that characterizes the soils in the dryland of the Chilean central coast range, having a low water holding capacity (66.4 $\mathrm{mm}$ in the soil profile) and high permanent wilting point increasing in the deepest horizons due to higher clay content.

The lower total porosity negatively affects root biomass in compacted soils (Martínez et al., 2011), due to the reduced soil aeration, reflecting a lower continuity and connectivity of macropores (Martínez et al., 2016). However, the contribution of slow drainage pores is important to improve the amount of usable water for the crop growth (Hartge and Horn, 2009). ZTS showed a volume of pores $(10-50 \mu \mathrm{m})$ higher in a $24 \%$ and $13 \%$ to ZT and CT, respectively. Mulumba and Lal (2008) indicated that the use of crop residues higher than $8 \mathrm{Mg} \mathrm{ha}^{-1}$ in an Alfisol, increased the usable water in ZT systems between 0 and $10 \mathrm{~cm}$ of depth. In the present study, the lower input of crop residues $\left(2.5 \mathrm{Mg} \mathrm{ha}^{-1}\right)$ was not enough to increase the total porosity in severely degraded soils. However, the soil cover resulting from residues left on the surface in conservation tillage systems, protect the soil surface by absorbing the energy from the impact of raindrops, especially during intense rainfalls (Martínez et al., 2012). In addtition, conservation tillage systems have shown a soil structure more stable than soils under conventional tillage as found by Martínez et al. (2008), Fuentes et al. (2009) and Álvarez and Steinbach (2009). The aggregate stability indices in the present study, evaluated by four years after the start of the trial, did not reveal any significant differences in the structural stability among tillage systems. This was probably due to the initial condition of the soils in the study area, where soil degradation is a severe problem (Martínez et al., 2012).

The variation of the weighted mean diameter indicated a loss of macro-aggregate stability as soil depth increased, so it is possible that the observed inter- aggregate porosity in the subsoil was the result of cracks caused by drying. The higher stability on the soil surface would indicate a structure that depends on processes related to adding organic matter as demonstrated by Martínez et al. (2008) in a Mollisol managed with ZT, where aggregate stability increased over time (4 to $7 \mathrm{yr}$ ). The high percentage of clay under the $20 \mathrm{~cm}$ soil depth was related to the dispersion ratio index, which indicated higher stability as the soil depth increased because of the presence of clay clusters (Chenu and Plante, 2006).

The airflow at a pressure of $-33 \mathrm{kPa}$ reflects the conductivity of drainage pores $(>10 \mu \mathrm{m})$. On the contrary to the expected, the surface airflow was lower in the three tillage systems, this could be due to a higher tortuosity of the coarse pore system (Dörner et al., 2009). Airflow values between 5 and $7 \mathrm{~cm} \mathrm{~h}^{-1}$ at the first 10 $\mathrm{cm}$ of depth were similar to the results obtained by Seguel et al (2015), which measured in a granitic soil cultivated with vines. As the soil depth increased, airflow increased in the deep clay-textured horizons by cracks produced by drying, being more effective than the structural porosity. The abrupt airflow changes between the evaluated horizons for the CT system could reflect a disruption in pore continuity that reduced the flow capacity between the plowed layer and the subsoil (Dexter et al., 2004). Thus, functionality of the soil system seems to be more influenced by the form, size, tortuosity, and degree of connection between pores than by total macro-pore volume (Dörner et al., 2009). At the $0-20 \mathrm{~cm}$ depth, conservation tillage systems had a higher number of roots per unit area with significant differences as compared with conventional tillage. Martínez et al., (2008) observed a similar result for the first $5 \mathrm{~cm}$ of soil with ZT management for 4 and $7 \mathrm{yr}$ versus a soil subjected to $\mathrm{CT}$. Although penetration resistance was not significantly different between treatments, the conservation tillage systems in compacted soils had rest coefficient ( $\mathrm{ko})$ values below the critical value $(\mathrm{ko}<1)$ as 
shown by Hartge and Bachmann (2004). Even though it was expected that soil under CT could exhibit better physical conditions for root growth because of the lower strength induced by plowing, it was observed that this tillage system reached values as high as those for ZT throughout the season, especially as a result of soil settlement (Agostini et al., 2012). Subsoiling would therefore be effective to reduce penetration resistance as depth increases (Nunes et al., 2015), but given the low physical mechanical stability of the soils (lower organic matter content as depth increases), the effect is rapidly lost from one season to another (Martínez et al., 2011).

The increased formation of biopores and structural pores produced by conservation tillage is associated with better soil structure and had a positive impact on root development and crop yield (Botta et al., 2010; Zhang et al., 2014). This was observed in the ZTS treatment where results surpassed CT and ZT systems for both the number of roots and root growth as the soil depth increased. Water absorption in this system could increase by a bigger and deeper root system (Kirkegaard and Lilley, 2007).

It was also observed a poor wheat root growth in the ZT treatment below $40 \mathrm{~cm}$ of depth, which was lower than the $80-180 \mathrm{~cm}$ of depth observed by other authors (Bonfil et al., 1999; Kirkegaard and Lilley, 2007). White and Kirkegaard (2010), also observed that the abundance of roots strongly decreased at a depth of 60 $\mathrm{cm}$ in the transition to a denser textured subsoil. This result is associated with the compaction effect that has been reported in clay-textured soils (Jin et al., 2007; Alvarez and Steinbach, 2009), and the high mechanical resistance observed in the deeper horizons of the profile in this study, which revealed a high degree of resistance that would limit root elongation during the driest period of crop development; this being a critical situation for a zone where root exploration is essential to increase crop water availability.

\section{Conclusions}

At the end of the 4-yr study, the results showed that soil physical parameters related to soil bulk density, porosity and aggregates were found to be similar in the conservation and convential tillage systems. However, the volume of pores with diameters between $10-50 \mu \mathrm{m}$ was significantly higher in ZTS. In addition, the higher slow drainage pores and abundance of surface roots observed in ZTS, increased the crop water availability under water stress conditions. The subsoiling was an essential complement to zero tillage, because it promoted a better root system in the first horizons and higher exploration at depth in these severely compacted soils.

\section{Acknowledgments}

Part of this study was conducted within the DESIRE Project financed by the European Union and the Dirección de Protección de Recursos Naturales of SAG, executed by INIA Quilamapu. The authors wish to thank Dr. Paola Silva and Marcelo Rodríguez, MSc, for their support in the discussions and the Interior Dryland Development Center of the Universidad Católica del Maule for their technical support.

\section{References}

Agostini, M., Studdert, G., San Martino, S., Costa, J., Balbuena, R., Ressia, J., Mendivil,

G., Lázaro, L. 2012. Crop residue grazing and tillage systems effects on soil physical properties and corn (Zea mays L.) performance. Journal of Soil Science and Plant Nutrition. 12 (2): 271-282.

Alvarez, R., Steinbach, H. 2009. A review of the effects of tillage systems on some soil physical properties, water content, nitrate availability and 
crops yield in the Argentine Pampas. Soil and Tillage Research. 104(1): 1-15.

Bonfil, D., Mufradi, I., Klitman, S., Asido, S. 1999. Wheat grain yield and soil profile water distribution in a No-Till arid environment. Agronomy Journal. 91, 368-373.

Botta, G., Tolon-Becerra, A., Lastra-Bravo, X., Tourn, M. 2010. Tillage and traffic effects (planters and tractors) on soil compaction and soybean (Glycine max L.) yields in Argentinean pampas. Soil and Tillage Research. 110, 167-174.

Chenu, C., Plante, A. 2006. Clay-sized organo-mineral complexes in a cultivation chronosequence : revisiting the concept of the "primary organomineral complex". European Journal of Soil Science. 57, 596-607.

Dane, J., Topp, G. 2002. Methods of soil analysis. Part 4. Physical methods. SSSA Book Ser. 5. SSSA, Madison, WI. $1692 \mathrm{p}$.

Dexter, A., Czyz, E., Gate, O. 2004. Soil structure and the satured hydraulic conductivity of subsoil. Soil and Tillage Research. 79, 185-189.

Dörner, J, Dec, D., Peng, X., Horn, R. 2009. Efecto del cambio de uso en la estabilidad de la estructura y la función de los poros de un andisol (Typic Hapludand) del sur de Chile. Revista de la Ciencia del Suelo y Nutrición Vegetal. 9(3):190-209.

Fuentes, M., Govaerts, B., de León, F., Hidalgo, C., Dendooven, L., Sayre, K., Etchevers, J. 2009. Fourteen years of applying zero and conventional tillage, crop rotation and residue management systems and its effect on physical and chemical soil quality. European Journal of Agronomy. 30(3): 228-237.

Glab, T., Kulig, B. 2008. Effect of mulch and tillage system on soil porosity under wheat (Triticum aestivum). Soil and Tillage Research. 99, 169-178.

Hartge, K., Bachmann, J. 2004. Ermitlung des Spannungszustandes von Böden aus Werten des Ein- dringwiderstandes von Sonden. Journal of Plant Nutrition and Soil Science. 167, 304 -308.

Hartge, K., Horn, R. 2009. Die physikalische Untersuchung von Böden: Praxis Messmethoden Auswertung. 4. vollst. Überarbeitete Auflage. Schweizerbart'sche Verlagsbuchhandlung, Stuttgart: $178 \mathrm{p}$.

Hong-Ling, Q., Wang-Sheng, G., Yue-Cun, M., Li, M., Chun-Mei, Y., Zhe, C., Chunlan, C. 2008. Effects of subsoiling on soil moisture under no-tillage for two years. Agricultural Sciences in China. 7(1): 88-95.

Jin, H., Hongwen, L., Xiaoyan, W., Mchugh, A., Wenying, L., Huanwen, G., Kuhn, N. 2007. The adoption of annual subsoiling as conservation tillage in dryland maize and wheat cultivation in northern China. Soil and Tillage Research. 94, 493-502.

Kirkegaard, J., Lilley, J. 2007. Root penetration rate a benchmark to identify soil and plant limitations to rooting depth in wheat. Australian Journal of Experimental Agriculture. 47, 590-602.

Lampurlanés, J., Cantero-Martínez, C. 2003. Soil bulk density and penetration resistance under different tillage and crop management system and their relationship with barley root growth. Agronomy Journal. 95, 526-536.

Martinez, E., Fuentes, J., Silva, P., Valle, S., Acevedo, E. 2008. Soil physical properties and wheat root growth as affected by no-tillage and conventional tillage systems in a Mediterranean environment of Chile. Soil and Tillage Research. 99(2): 232-244.

Martínez, I., Ovalle, C., del Pozo, A., Uribe, H., Valderrama, N., Prat, C., Sandoval, M., Fernández, F., Zagal, E. 2011. Influence of conservation tillage and soil water content on crop yield in dryland compacted Alfisol of Central Chile. Chilean Journal of Agricultural Research 71, 615-122. 
Martínez, I., Prat, C., Ovalle, C., del Pozo, A., Stolpe, N., Zagal, E. 2012. Subsoiling improves conservation tillage in cereal production of severly degraded Alfisols under Mediterranean climate. Geoderma. 189-190: 10-17.

Martínez, I., Chervet, A., Weisskopf, P., Sturny, W.G., Rek, J., Keller, T. 2016. Two decades of no-till in the Oberacker long-term field experiment: Part II. Soil porosity and gas transport parameters. Soil Till. Res. 163: 130-140.

Mulumba, L., Lal, R. 2008. Mulching effects on selected soil physical properties. Soil and Tillage Research. 98, 106-111.

Nunes, M.R., Denardin, J.E, Pauletto, E.A, Faganello, A., Spinelli Pinto, LF. 2015. Mitigation of clayey soil compaction managed under no-tillage. Soil and Tillage Research. 148, 119-126.

Peth, S. 2004. Bodenphysikalische Untersuchungen zur Trittbelastung von Böden bei der Rentierweidewirtschaft an borealen Wald- und subarktisch-alpinen Tundrenstandorten Auswirkungen auf thermische, hydraulische und mechanische Bodeneienschaften. Schriftenreihe des Instituts für Pflanzenernährung und Bodenkunde, H. 64, ISSN: 0933-680.

Radicetti, E., Mancinelli, R., Moscetti, R., Campiglia, E. 2016. Management of winter cover crop residues under different tillage conditions affects nitrogen utilization efficiency and yield of eggplant (Solanum melanogena L.) in Mediterranean environment. Soil and Tillage Research. 155, 329-338.
Richards, D. 1983. The grape roots system. Horticultural Reviews. 5, 127-128.

SAS INSTITUTE. 1999. SAS/STAT user's guide, Version 8. SAS Institute INC., Cary, NC. 3848 P.

Schoeneberger, P., Wysocki, D., Benham, E., Broderson, W. 2002. Field book for describing and sampling soils. Version 2.0. Lincoln, USA, National Soil Survey Center, Natural Resource Conservation Service, USDA.

Seguel, O., Garcia de Cortazar, V., Casanova, M. 2003. Variación en el tiempo de las propiedades físicas de un suelo con adición de enmiendas orgánicas. Agricultura Técnica. 63 (3): 287-297.

Seguel, O., Horn, R. 2006. Structure properties and pores dynamics in aggregate beds due to wettingdrying cycles. Journal Soil Science and Plant Nutrition. 169, 221-232.

Seguel, O., Farías, E., Luzio, W., Casanova, M., Pino, I., Parada, A.M., Videla, X., Nario, A. 2015. Physical properties of soil after change of use from native forest to vineyard. Agro Sur. 43(2): 29-39.

White, R., Kirkegaard, J. 2010. The distribution and abundance of wheat roots in a dense, structured subsoil-implications for water uptake. Plant, Cell and Environment. 33, 133-148.

Zhang, P., Wei, T, Jia, Z., Han, Q., Ren, X. 2014. Soil aggregate and crop yield changes with different rates of straw incorporation in semiarid areas of northwest China. Geoderma. 230-231, 41-49. 